\title{
SOMETHING FOR NOTHING: THE LAW OF ADVERSE POSSESSION IN ALBERTA
}

\section{SANDRA PETERSSON}

\begin{abstract}
This paper is the winner of this year's William Morrow Essay competition. It traces the origin and evolution of the law of adverse possession. Petersson commences with a thorough overview of the current status of adverse possession in Canada. The reader is then transported back in time to medieval England to bear wimess as historical forces forge the law into twin principles of extinction and acquisition. From the regal court of Henry II, the reader is then whisked to the humble offices of the Registrar of Land Titles as the paper guides one through modern property law relating to adverse possession. The journey ends with an enlightening discussion of the justifications for, and future of, adverse possession in Albersa.
\end{abstract}

Le présent article a remporté le prix du concours William Morrow Essay de cette année. II retrace l'origine et l'évolution du droit de la possession adversative. Petersson commence par un examen approfondi du statut actuel de la possession adversative au Canada. Le lecteur est ensuite transporté dans l'Angleterre médiévale et assiste aux forces historiques qui ont forgé les deux principes jumeaux d' extinction el d' acquisition. Puis le lecteur passe ensuite du faste de la cour de Henry II aux humbles bureaux du Conservateur des titres fonciers. tandis que lauteure le guide à travers le droit moderne de la propriété traitant de possession adversative. Les péripéties se terminent par une discussion instructive où l' auteure justifie ce principe en Alberta et parle de son avenir.

\section{TABLE OF CONTENTS}

I. INTRODUCTION . . . . . . . . . . . . . . . . . . . . . . . 1292

II. PLACE OF ADVERSE POSSESSION IN CANADA . . . . . . . 1293

A. PRESCRIPTION AND ADVERSE POSSESSION . . . . . 1293

B. OVERVIEW OF LAND HOLDING AND ADVERSE POSSESSION IN CANADA . . . . . . . . . . . . . . 1294

III. HISTORICAL DEVELOPMENT OF THE LAW

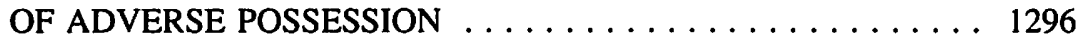

A. COMMON LAW .................... 1296

B. DEVELOPMENT OF THE PRINCIPLE OF EXTINCTION . . . . . . . . . . . . . . . . . . . . . 1296

C. DEVELOPMENT OF THE PRINCIPLE

OF ACQUISITION . . . . . . . . . . . . . 1300

IV. CURRENT STATUS OF THE LAW OF

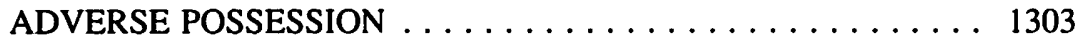

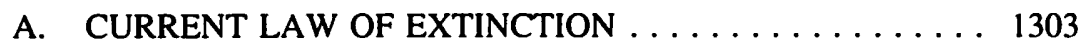

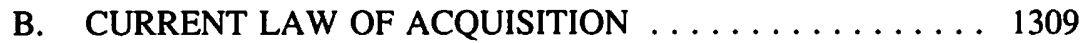

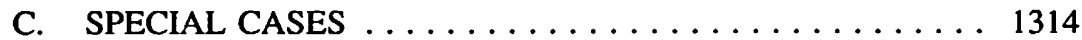

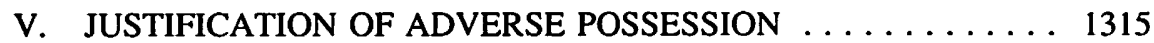

A. CONSISTENCY WITH THE

TORRENS SYSTEM ................ 1315

B-és-Arts, LL.B., Member of the Alberta Bar and will be clerking at the Supreme Court of Canada in 1993. 


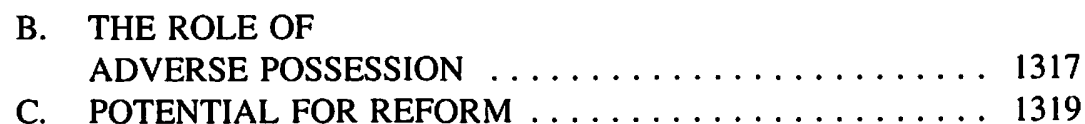

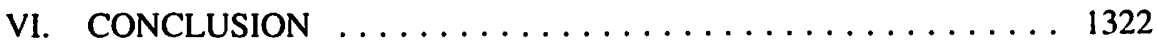

TABLE OF CONCORDANCE OF

ALBERTA STATUTES $\ldots \ldots \ldots \ldots \ldots \ldots \ldots \ldots \ldots \ldots, 1323$

\section{INTRODUCTION}

[M]an, like a tree in a cleft of a rock, gradually shapes his roots to his surrounding, and when the roots have grown to a certain size, cannot be displaced without cutting at his life.'

The above statement by Justice Holmes reflects the special status land receives in our concept of property. If another person uses your bank account over a number of years, without your permission, that person is not entitled to the money in your account. Yet this is in effect what happens under the law of adverse possession. If you do not exert your ownership for a period of ten years, your rights and title to the land can be extinguished by the Limitation of Actions Act and another person can become the registered owner in your place under the Land Titles Act. In contrast to most personal property, land lasts forever and will have many owners. As a result, our notion of "ownership" of land refers only to a bundle of rights exercisable with respect to the land. Adverse possession provides a means to transfer those rights to someone in a better position to use them.

Adverse possession, also colloquially known as squatter's rights, fits with our history of homestead settlement. However, the notion of adverse possession developed in Medieval England when most land was already spoken for. Methods of land holding have greatly changed since that time. The prevailing view seems to be that adverse possession is inconsistent with the current system of land holding in Alberta, the Torrens system. Indeed, many similar systems have abolished adverse possession. However, in Alberta the position of adverse possession has been strengthened by legislation. In this province, adverse possession works within the Torrens system and not against it. There is no inconsistency between the two when looked at from the basic purpose of any Torrens system.

Actions for adverse possession are rare. Often claims are settled quietly without litigation. This reflects the many purposes adverse possession can still play in a modern system of land holding. This is not to say that the current law of adverse possession in Alberta is without defect. Certainly the law does result in injustice at times. However, the negative results of adverse possession are not enough to warrant its abolition as some propose. Rather, future reform should be along the lines of previous amendments to the Land Titles Act, correcting the legislation as the case law reveals problems.

1. O.W. Holmes, cited in Lerner, The Mind and Faith of Justice Homes: His Speeches, Essays, Letters and Judicial Opinions (Boston: Little Brown, 1953) at 417. 
This paper is divided into 4 main sections. The first section presents the overall status of adverse possession in Canada. This includes a brief explanation of the difference between adverse possession and prescription. The second section sets out the historical development of the law of adverse possession, and outlines the evolution of its two main principles, extinction and acquisition. Tracing the development of the doctrine into current Alberta law shows a deliberate reinforcement of these two main principles. Third, the paper discusses the current law of adverse possession in Alberta as it is found both in statute and at common law, including adverse possession of Crown land and mines and minerals. Against this backdrop, the fourth section discusses whether or not adverse possession is justified.

\section{PLACE OF ADVERSE POSSESSION IN CANADA}

\section{A. PRESCRIPTION AND ADVERSE POSSESSION}

Cases often refer to the "acquisition of title by prescription" or "prescriptive title," ignoring a basic distinction in terminology. There are two traditional means by which B can gain an interest in land owned by $\mathrm{A}$ - prescription and adverse possession. The difference between them lies in the nature of the interest B obtains in A's land and the acts supporting B's acquisition. Prescription results in the acquisition of rights in another's land, such as an easement, right of way, or profit-à-prendre. Adverse possession, in contrast, leads to acquisition of title to another's land. Whether B gets rights or title depends on the acts B undertakes with respect to A's land. Prescription arises where B's acts amount to adverse use or enjoyment, falling short of possession. Adverse possession requires B's occupation of the land to a degree inconsistent with A's ownership. What will be sufficient to gain title, as opposed to amounting to a mere prescriptive right, is not easily defined in advance. As Professor Williams stated, ${ }^{2}$

It may be regarded simply as a question of degree whether title or merely... [a prescriptive right] may be acquired.... The sort of acts that might open into servitudes over another's large tract of land might amount to full de facto occupation of a more limited area of the same land.

Clearly, a claim in adverse possession requires evidence of acts more strongly in opposition to the true owner's title than will a claim for prescriptive rights, just as the latter requires stronger acts than an action in trespass.

Prescriptive rights were abolished in Alberta by An Ordinance Respecting Limitation of Action in Certain Cases, O.N.W.T. 1903(2), no. 7, s. 1. This is now section 50 of the Limitation of Actions Act, R.S.A. 1980, c. L-15.

50. No right to the access and use of light or any other easement, right in gross or profit-à-prendre shall be acquired by a person by prescription, and it shall be deemed that no such right has ever been so acquired.

2. J.S. Williams, Acquisition of Title to Land by Adverse Possession (Faculty of Law, University of Sheffield. 1968) [unpublished] at 2. 
Easements and similar interests in land still exist, but they must be expressly created or arise by implication. It may at first seem odd that, having done away with prescriptive rights, Alberta still allows adverse possession. However, a prescriptive right impedes the owner's use of the land. If B gains a prescriptive easement over land A holds in fee simple, A cannot make any use of land which will derogate from B's easement. If B registers the easement under the Land Titles Act, any transferee of title from A will also be subject to B's easement, taking not a fee simple, but a fee simple subject to an easement. ${ }^{3}$ The value of A's land and A's ability to transfer the land are reduced by B's easement. In contrast, if $B$ acquires title to A's land by adverse possession $B$ acquires the whole of $A$ 's fee simple. Or whatever interest $A$ had. $A s B$ is a volunteer to the land, B's title will be subject to any unregistered interests that bound A's title. B gets exactly what A had. Similarly, transferees from B also take without a reduction of the interest. The devaluation caused by prescriptive rights perhaps explains the sole abolition of prescription.

\section{B. OVERVIEW OF LAND HOLDING AND ADVERSE POSSESSION IN CANADA}

Among the common law jurisdictions in Canada, there are two systems of land holding - registry and Torrens. Under the registry system all deeds pertaining to land are filed by name of purchaser or grantee at a central registry. Nova Scotia, Prince Edward Island, and Newfoundland use registry systems. ${ }^{4}$ Under a Torrens system, the government retains custody of all original certificates of title to land and guarantees their accuracy. Torrens systems are used in British Columbia, Alberta, Saskatchewan, and in the Yukon and Northwest Territories. ${ }^{5}$ Ontario, New Brunswick and Manitoba are mixed registry and Torrens jurisdictions. ${ }^{6}$ Adverse possession is much more prevalent under registry systems. ${ }^{7}$ However, this paper discusses adverse possession in the Torrens context, specifically within Alberta.

There are two approaches to adverse possession in a Torrens system. It is either allowed, or essentially abolished. The trend in Canada has been to eliminate adverse possession on the ground that it is inconsistent with basic Torrens principles. For example, the Saskatchewan Land Titles Act, R.S.S. 1978, c. L-5 prevents adverse possession after 1913:

Section 65(1)(g) of the Land Titles Act, R.S.A. 1980, c. L-5 specifically lists easements as an implied condition binding a certificate of title. Unless otherwise specified, future references are to the R.S.A. 1980 Land Titles Act.

4. Registry Act, R.S.N.S. 1989, c. 392; Registry Act, R.S.P.E.I. 1988, c. R-10; Registration of Deeds Act, R.S.N. 1990, c. R-10. Both Nova Scotia and Prince Edward Island passed Torrens legislation that remained unproclaimed and was dropped in the latest revised statutes.

5. Land Titles Act, R.S.B.C. 1979, c. 219; Land Titles Act, R.S.A. 1980, c. L-5; Land Titles Act, R.S.S 1987, c. L-5; Land Titles Act, R.S.C. 1985, c. L-5.

6. Land Titles Act, R.S.O. 1990, c. L-5 and Registry Act, R.S.O. 1990, c. R-20; Land Titles Act, S.N.B. 1981, c. L-1.1 and Registry Act, R.S.N.B. 1973, c. R-6; Real Property Act, C.C.S.M., c. 30.

7. For example, Quick Law's Dominion Reports Service database retrieves over 200 cases on adverse possession since 1968. Limiting this to the pure Torrens jurisdictions cuts the number to less than 20. Similarly, the Canadian Judgments database retrieves 140 adverse possession cases since 1985 , of which only a handful are from pure Torrens systems. 
71(1). Every certificate of title shall be void as against the title of any person adversely in actual occupation of and rightly entitled to the land at the time when the land was brought under this act.

7I(2). After land has been brought under this Act no right, title or interest adverse to or in derogation of the title or of rights to the possession of the registered owner shall be acquired, or held to have been acquired since December 19,1913, by the possession of another, and the right of a registered owner to make an entry or to bring an action or suit to recover the land of which he is such registered owner shall not be held to be or to have been impaired or effected by any such possession since the said date.

An identical provision is found in An Act Respecting Real Property and the Title Thereto, C.C.S.M., c. R-30, s. 61. Adverse possession in Saskatchewan and Manitoba, therefore, is only available against land which has not been brought under the Torrens system, and against unregistered interests such as life estates or future estates. Saskatchewan reinforces its position against adverse possession by providing that the Land Titles Act is paramount to the Limitation of Actions Act. ${ }^{8}$ British Columbia also doubly prevents adverse possession by excluding adverse claims against land already under the Torrens system and by not prescribing a limitation period for the recovery of land. ${ }^{9}$ Even in the mixed registry-Torrens jurisdictions, adverse claims cannot be made against Torrens land. Twice, the Supreme Court of Canada has ruled that the Ontario legislation clearly states that adverse possession cannot affect a Torrens registered title. ${ }^{10}$ The prevalent view in Canada is that adverse possession and the Torrens system cannot work together. The Saskatchewan Law Reform Commission neatly summarizes the situation: "The Torrens system has eroded the importance of possession as a basis for asserting title to land. Registration is now the key to ownership. ...it would be appropriate to abandon the notion that possession can create an interest in land."11

Limitation of Actions Act, R.S.S. 1978, c. L-15, s. 17: "This Part is subject to the Land Titles Act." Land Titles Act, R.S.B.C. 1979, c. 219, s. 23.

23(2) After an indefeasible title is registered, no title adverse to or in derogation of the title of the registered owner shall be acquired by length of possession.

23(3) Notwithstanding subsection (2), in case only of the first indefeasible title registered,. it is void against the title of a person adversely in actual possession of and rightly entitled to the land included in the indefeasible tide at the time registration was applied for and who continues in possession.

And Limitation Act, R.S.B.C. 1979, c. 236. s. 12: "Excepl as specifically provided by this or any other Act, no right to title in or to land may be acquired by adverse possession." Smith v. National Trust Co. (1912), 45 S.C.R. 618; Gatz v. Kiziw, [1959] S.C.R. 10. Both cases were in reference to what is now the Land Tilles Act, R.S.O. 1990, c. L-5, s. 54.

54. Notwithstanding any provision of this Act, the Limitations Act or any other Act, no title to and no right or interest in land registered under this Act that is adverse to or in derogation of the title of the registered owner shall be acquired thereafter or be deemed to have been acquired heretofore by any length of possession or by prescription.

This section does not prejudice, as against any person registered as first owner of land with a possessory title only, any adverse claim in respect of length of possession of any other person who was in possession of the land at the time when the registration of the first owner took place.

11. Law Reform Commission of Saskatchewan, Proposals for a New Limitation of Actions Act (Report to the Minister of Justice) (Saskatoon: Law Reform Commission of Saskatchewan, April 1989) at 25. 
Within Canada, only Alberta permits adverse possession within a Torrens system. Alberta's position is not unique. Notably, some Australian states allow adverse possession to exist along side Torrens legislation. Why has Alberta chosen to preserve adverse possession while other Canadian provinces have not? Is this just an oversight in legislative reform? Or does adverse possession serve a purpose in a modern system of land holding? The answers to these questions are revealed through looking at historical development of adverse possession, the current status of the law in Alberta, and the purpose of the Torrens system.

\section{HISTORICAL DEVELOPMENT OF THE LAW OF ADVERSE POSSESSION}

\section{A. COMMON LAW}

The modern law of adverse possession in Alberta comprises two principles: extinction, which causes the owner to lose title to the land, and acquisition, which permits the adverse possessor to obtain title. Neither principle was known at common law. Title to land at common law depended upon seisin. Whoever could show the earliest and, therefore, the better seisin would have priority to the land. In a largely illiterate society, possession was strong evidence of seisin, and the action to recover land became one of showing prior possession. ${ }^{12}$ The owner, as evidenced by prior possession, could bring an action to recover possession at any time. The problems with such a system are twofold. As time passes it becomes increasingly difficult for the dispossessed owner to prove the claim. Correspondingly, as the adverse possessor becomes more settled on the land, ejectment would be unjust, especially where improvements have been made. Consequently legislation was enacted to make title to land more certain.

\section{B. DEVELOPMENT OF THE PRINCIPLE OF EXTINCTION}

\section{Limitation By Reference to Historic Events}

The earliest legislation aimed at making title more certain limited the action for recovery of land by reference to a certain historical event. The first such legislation occurred during the reign of Henry II. ${ }^{13}$ To recover land from an adverse possessor, the owner had to show seisin of the land at the time of the king's last voyage to Normandy. Failing this, title would go to the adverse possessor. Due to the frequency of the king's visits, the length of the period for recovery varied. Later limitation dates of the coronation of Henry III in 1216, of Henry III's first trip to Gascony, ${ }^{14}$ and, finally, of

12. Stating that the action was one to recover land is a simplification. There were a variety of different writs relating to dispossession of land. These were all later abolished or consolidated into the action for recovery of land by The Real Property Limitation Act, 1833, (1833) 3 \& 4 Will. IV., c. 27, s. 36. To avoid confusion the action will be referred to as that for the recovery of land. 
the coronation of Richard $\mathrm{I}^{15}$ were also set by statute. The early history of adverse possession legislation was further complicated by each different writ having a separate limitation date.

\section{Introduction of "Modern" Preclusive Limitation Periods}

The limiting date of September 3, 1189 endured for 265 years, losing all effectiveness. The next stage in the development of limitations legislation was establishing "modern" preclusive limitation periods. A prescribed period was set out within to bring an action for recovery of land. The first preclusive statute, The Act of Limitation with Proviso, (1540) 32 Hen. VIII, c.2, s. I, prescribed three score years. If the owner could not prove seisin of the land within the sixty preceding years, the remedy to recover land was barred. Correspondingly, if the adverse possessor could show possession for sixty years, ejectment was not available. ${ }^{16}$ Although this legislation more closely resembles its modern counterpart, it does not yet embody the principle of extinction. Only the owner's remedy was barred, not the right and title to the land itself. ${ }^{17}$ Thus if the bare legal owner could regain possession the result would be priority over the adverse possessor by virtue of the earlier seisin.

The principles of extinction was not introduced until An Act for the Limitation of Actions and Suits relating to Real Property and for simplifying the Remedies for trying the rights thereto, (1833) 3 \& 4 Will. IV., c. 27. The Real Property Limitation Act, 1833, as it is most commonly called, is the closest ancestor to the modern limitation periods. The period for bringing an action for recovery of land was shortened to twenty years by section II. ${ }^{18}$ The most innovative feature of the 1833 Act is the principle of extinction contained in section 34 .

XXXIV. And be it further enacted. That at the Determination of the Period limited by this Act to any Person for making an Entry or Distress, or bringing any writ of Quare impedit or other Action or Suit, the Right and Title of Such Person to the Land, Rent, or Advowson for the Recovery whereof such Entry. declare of the seisin of his Ancestor further, or beyond the Time of King Richard, Uncle to King Henry, Father to the King that now is. for exercising rights of entry was reduced to 20 years in Act for the Limitation of Actions and for avoiding of Suits in Law, 1623, 21 Jac. I, c. XVI and later to only 1 year under An Act for the Amendment of the Law and the Better Advancement of Justice, (1705), 4 \& 5 Ann., c. 16.

17. The Act of Limitation with Proviso (1540), 32 Hen. VIII, c.2, s. VI.

18. The Real Property Limitation Act, 1833, 3 \& 4 Will. IV., c. 27, s. II:

...no person shall make Entry or Distress or bring an Action to recover any Land or Rent but within Twenty Years next after the Time at which the Right to make such entry or Distress or to bring such Action shall have first accrued to some person through whom he claims; or if suc, Right shall not have ace led to any Person though whom he clairs, then within Tu.... Years nest after the Time at unich the Right to make su h Entry or L) -ss or to bring such Action shal! have first accrued to th. person bringing the same. 
Distress, Action or Suit respectively might have been made or brought within such Period, shall be extinguished. [emphasis added].

Limitation statutes are typically procedural in nature, merely preventing the enforcement of the remedy, leaving the substantive right intact. Section 34, however, extinguishes both remedy and right. Stuart J. summarized the impact of section 34 in Re Anderton (1908), 8 W.L.R. 319 at 320 (Alta. S.C.):

Prior to the passing of that section, the effect of the statute had been merely to bar the remedy but not the right of the legal owner. Section 34 expressly declared that the right of the legal owner should cease to exist as soon as his remedy was barred by the statute, and it was owing to the supposed effect of this section that in a number of cases the person whose length of possession had barred the legal owner, was held to have acquired a positive title in himself.

From this point onwards, the bare legal owner was no longer able to get priority to the land simply by regaining possession as the owner no had had rights to the land. This removed the conveyancing hindrance of the prior owner out of possession. Further, section 34 was also held to be retroactive, being applicable where the limitation period had begun before the passing of the act. ${ }^{19}$ Once the limitation period had run the owner was no longer a threat to the adverse possessor and security of the adverse title was increased. Without more, however, a documentary system of land holding would still show title in the mere "paper" owner.

The Real Property Limitation, 1833, being in force on July 15, 1870, was received as law in Alberta, "in so far as applicable. ${ }^{20}$ The first limitation period for recovery of land in Alberta was, therefore, twenty years. The English Parliament shortened the limitation period to twelve years with the passage of The Real Property Limitation Act, 1874, 37 \&38 Vict., c. 57, s. 1. The 1874 Act did not automatically apply in the Northwest Territories. However, twelve year limitation period was adopted by An Ordinance Respecting the Limitation of Actions Relating to Real Property, O.N.W.T. 1893, no. 28, s. 1:

The provisions of The Real Property Limitation Act, 1874, being chapter 57 of the Statutes of the Imperial Parliament, passed in the thirty-seventh and thirty-eighth years of Her Majesty's reign are hereby declared to be in force and shall to have been in force, in the Territories since the passing thereof.

The Ordinance continued in force in the new province of Alberta by The Alberta Act, S.C. 4-5 Edw. 7, c. 3. Alberta expressly affirmed the Ordinance as its own in The Limitation of Action Act, R.S.A. 1922, c. 90, s. 3. The Real Property Limitation Act, 1874 was not repealed in Alberta, until 1935 when the Uniform Limitation of Actions Act was adopted. The Limitation of Actions Act, 1935. S.A. 1935, c. 8, s. 52, shortened the limitation period for recovery of land to ten years by section 17. The current Limitation of Actions Act, R.S.A. 1980, c. L-15 reads as follows: 
18. No person shall take proceedings to recover land except

(a) within 10 years next after the right to do so first accrued to that person (hereinafter called the "claimant"), or

(b) if the right to recover first accrued to a predecessor in title, then within years next after the right accrued to that predecessor.

44. At the determination of the period limited by this Act to any person for taking proceedings to recover any land, rent charge or money charge or land the right and title of that person to the land, or rent charge or the recovery of the money out of the land is extinguished.

The wording is more modern but the substantive effect of the provision is unchanged. In certain circumstances section 18 can be circumvented by framing the action, not as one to recover land, but as one for clarification of title. Such an action can be brought at any time. In summary, title is extinguished in Alberta if the owner out of possession does not bring action to recover the land within ten years. The owner loses the remedy of recovery by section 18 of the Limitation of Actions Act $t^{21}$ and right and title are extinguished by section 44 .

\section{Proposed Reform of Limitations Legislation}

The Alberta Institute of Law Research and Reform has proposed legislation that would affect the principle of extinction. The Institute favours the abolition of adverse possession but has held off in reform of this area until a later day. ${ }^{22}$ Under the Institute's proposed model Act an action for recovery of land falls under the "ultimate rule." Section 3(1)(b) of the model act allows the owner fifteen years from the date of dispossession to apply for recovery. Adverse possession is specifically exempted from the application of the "discovery rule." Section 3(4) of the model act specifies claims that must be brought within two years of discovery. Applying section 3(4) to adverse possession would require the owner to bring action within two years of when the owner ought to have discovered the adverse possessor. As adverse possession requires overt occupation, the owner's remedy becomes barred after only two years of adverse possession. Exempting adverse possession from the discovery rule is, therefore, justified.

In addition to altering the limitation periods the model act makes them entirely procedural. The foundation of extinction, the current section 44 , has no counterpart in the model act. Should the Institute's proposal be adopted it will be a step backwards, reestablishing an uncertainty of title that was done away with by The Real Property Limitation Act, 1833. The paper owner will once again be able to regain priority merely

\footnotetext{
21. $\quad$ C.P.R. v. Turta, (1954), 12 W.W.R. 97 (S.C.C.); Edwards v. Duborg. [1982] 6 W.W.R. 128 (Q.B.); Re Pogue and Lane, (1951) 3 W.W.R. (N.S.) 97 (Alta. S.C.). However, a clarification action can be defenced by evidence of adverse possession, showing that by section 44 the owner hs not title to clarify. The alternative action is of no value where adverse possession is cstablished.

22. See Limitations (Report For Discussion No. 4) (Edmonton: Alberta Institute of Law Research and Reform, September 1986) at 209, and Limitations (Report No. 55) (Edmonton: Alberta Institute of Law Research and Reform, December 1989) at 39.
} 
by obtaining possession. There is room for reform in the law of adverse possession, but not in the direction pointed by the Institute.

\section{DEVELOPMENT OF THE PRINCIPLE OF ACQUISITION}

It makes little sense to allow the extinction of the owner's title without providing for another to assume title. This is the role filled by the principle of acquisition. Although extinction is statute based, the acquisition principle developed through the common law in response to the extinction. Logically, upon the extinction of the owner's title the person with the best priority to the land was the adverse possessor. The common law recognized this be many statutory schemes of land holding do not. In Alberta, however, the Torrens system has been adjusted to allow for acquisition.

\section{The Land Titles Act}

Initially the Northwest Territories were not a Torrens jurisdiction. A registry system was established by An Ordinance Respecting the Registration of Deeds and Other Instruments Relating to the Lands in the North-West Territories, O.N.W.T. 1879, no. 9, and its later consolidation, Registration of Titles Ordinance of 1884 , O.N.W.T. 1884, no. 2. All registry legislation was repealed in the 1898 revision. ${ }^{23}$

In 1886 land holding in the Northwest Territories was brought under federal legislation. The Territories Real Property Act, S.C. 1886, c. 26 introduced a Torrens system, that is not far different from the current legislation. Adverse possession is provided for in two sections of the federal legislation:

50. Any person having an adverse claim or a claim not recognized in the application for registration may, at any time before the judge has approved of the applicant's title, file with the registrar a short statement of his claim, verified by affidavit, and shall serve a copy thereof on the applicant, his solicitor or agent.

51. If an adverse claim is filed, the judge shall proceed to examine into and adjudicate thereon, and no certificate of title shall be granted until the adverse claim has been disposed of.

More than a century later these provisions are still in force in The Land Titles Act, R.S.C. 1985 , c. L-5, although they are no longer of any consequence in Alberta. As with the limitations legislation, the federal Land Titles Act was continued in force in the new province of Alberta by the Alberta Act, S.C. 4-5 Edw. 7, c. 3. However, Alberta was quick to introduce its own legislation, The Land Titles Act, S.A. 1906, c. 24. The original adverse claims provisions from the federal legislation remain little changed in the current legislation. ${ }^{24}$

42(1) Any person having an adverse claim or a claim not recognized in the application for registration may, at any time before the judge has approved of the applicant's title, file with the Registrar a short 
statement of his claim, verified by affidavit, and shall serve a copy thereof on the applicant, his solicitor or agent.

(2) If an adverse claim is filed, the judge shall proceed to examine into and adjudicate thereon, and no certificate of title shall be granted until the adverse claim has been disposed of.

Section 42 is a starting point but is not the basis for the acquisitive principle. Section 42 empowers a judge to consider adverse claims when the owner applies to bring land under the Land Titles Act. The section will not support an application by the adverse possessor to bring land under the Act. ${ }^{25}$ The limited purpose of section 42 is to prevent overlooking an adverse possessor when bringing land under the Torrens system. ${ }^{26}$ At that isolated time, the balancing of interest may weigh in favour of the adverse possessor and deny the owner's claim. Otherwise section 42 adds little to the law of adverse possession in Alberta, especially now that nearly all private land is already under the system.

In other Torrens provinces later amendments to land titles legislation all but eliminate adverse possession, but later amendments in Alberta facilitate such claims. Two subsequent sections entrench adverse possession. The first was introduced in 1921 by $A n$ Act to Amend the Land Titles Act, S.A. 1921, c. 39, s. 2. The amending legislation added section 50(a), the adverse possession provision, to the 1906 Act:

50(a). Any person heretofore or hereafter recovering a judgment against a registered owner of land, declaring that the said person recovering the said judgment is entitled to the exclusive right to use the said land or that he be quieted in the exclusive possession thereof by reason of adverse possession, pursuant to An Ordinance respecting Limitation of Actions in Certain Cases, being chapter 31 of the Consolidated Ordinances of the North-West Territories. 1898, or any Act passed in amendment thereof or in substitution therefor, may file a certified copy of such judgment in the land titles office for the proper registration district. At the expiration of three months after the filing thereof, the registrar unless he is satisfied that an appeal from the said judgment is being taken shall make a memorandum upon the certificate of title in the register, cancelling the same, either wholly or partially, according to the tenor of the said judgment and setting forth the particulars of the said judgment.

Section 50(a), now section 74, provides statutory support for acquisition, but does not change the common law requirements for adverse possession. Either the owner brings an action for recovery of land or the adverse possessor one for quieting of title and the judge issues a declaratory judgment. A person who has proven an adverse claim can get valid Torrens title to the land and enjoy the protection of Torrens registration. The paper owner can finally be removed from the picture.

There have been two further amendments to the statutory acquisition section. The first, in 1945, struck out the words "by reason of adverse possession." ${ }^{27}$ Whatever other 
reason may have been behind the 1945 amendment, it rendered an earlier statement by Harvey C.J.A. of no effect: ${ }^{28}$

But it is to be observed that the judgment must declare that it was obtained "by reason of adverse possession" and I am of the opinion that, notwithstanding the words, "pursuant to The Limitation of Action Act" follow immediately, there was an intention to modify The Real Property Limitation Act, 1874, to the extent of the necessity for proving "adverse possession" in cases coming under necessity for proving "adverse possession" in cases coming under The Land Titles Act. I think we should in any event read into the Imperial Act, as far as The Land Titles Act is concerned, the requirement of proving "adverse possession."

The common law previously recognized acts of possession that were adverse and other that were not. Subsequent cases paid no attention to Harvey's statement in any event.

Forty years later, the second amendment eliminated the three month waiting period before the registrar can cancel the registered owner's title and issue a new certificate in favour of the adverse possessor. As amended section 74 currently reads:

74(1) Any person recovering against a registered owner of land a judgment declaring that the person recovering the judgment is entitled to the exclusive right to use the land or that he be quieted in the exclusive possession thercof, pursuant to the Limitations of Actions Act, may file a certified copy of the judgment in the Land Titles Office for the proper registration district.

(2) Subject to section 180.1 the Registrar shall

(a) enter on the certificate of title a memorandum cancelling the certificate of title, in whole or in part, according to the terms of the judgment, and

(b) issue a new certificate of title to the person recovering the judgment.

\section{Improvements to Land}

A second section that entrenches adverse possession and the acquisition principle was introduced in 1950. An Act to Amend the Land Titles Act, S.A. 1950, c. 35, s. 11 added section 173(a) to what was then Land Titles Act, R.S.A. 1942, c. 205. The provision was shifted in the 1980 revision to the Law of Property Act, R.S.A. 1980, c. L-8 and remains as section 60 of that Act:

60(1) When a person at any time has made lasting improvements on land under the belief that the land was his own, he or his assigns

(a) are entitled to a lien on the land to the extent of the amount by which the value of the land is enhanced by the improvements, or

(b) are entitled to or may be required to retain the land if the Court is of the opinion or requires that this should be done having regard to what is just under all circumstances of the case.

(2) The person entilled or required to retain the land shall pay any compensation that the Court may direct. 
Section 60 of the Law of Property Act is an alternative means of acquisition, the main difference being the ability of the court to require compensation to the owner.

In brief overview, the law of adverse possession in Alberta is a mix of statute and common law. The principle of extinction is based in the Limitation of Actions Act. The common law determines whether the nature of occupation merits extinguishing the owner's title. The principle of acquisition developed as a common law response to extinction but now enjoys statutory support in Alberta in section 74 of the Land Titles Act and section 60 of the Law of Property Act. Viewed historically, legislation in Alberta has evolved in favour of adverse possession, both by decreasing the limitation period for recovery of land and by recognizing title acquired by adverse possession as valid in the Torrens context. This entrenchment of adverse possession indicates of its utility in modern land holding. Further evidence of this can be gained by looking at the case law.

\section{CURRENT STATUS OF THE LAW OF ADVERSE POSSESSION}

There are roughly two dozen reported Alberta cases concerning the law of adverse possession. Adverse possession claims are brought more frequently than the reported cases show but are often dealt with in Chambers. Given the development of the law in Alberta cases from other provinces are of limited value. Such cases are relevant, however, to help define the common law requirements for establishing adverse possession. This section of the paper discusses what is necessary in Alberta to establish both extinction and acquisition. Extinction will be dealt with first.

\section{A. CURRENT LAW OF EXTINCTION}

\section{Running of Time}

The statutory requirement for extinguishing the owner's title is the adverse possessor's ten year occupation of the land as set out in section 18 of the Limitation of Actions Act. The burden of proof is on the party relying on the limitation period. ${ }^{29}$ This is adverse possessor, regardless of whether the adverse possession is raised in an action to quiet title or in defence to an action for recovery of land. To discharge the onus, the adverse possessor must show clear, strong, and satisfactory evidence to support the claim. ${ }^{30}$ To determine when the limitation period has expired it is necessary to know when it began. Section 19 provides that the limitation period begins when the owner is dispossessed:

19. When in respect of the estate or interest claimed the claimant or a predecessor has

(a) been in possession of the land or in receipt of the profits thereof, and

(b) while entitled thereto

(i) been dispossessed, or

(ii) discontinued that possession or receipt,

30. Re Anderton, supra, note 29 at 336 (Alta. S.C.). referring to Re Caverhill (1872), 8 C.L.J. 50 (Ch). 
the right to take proceedings to recover the land shall be deemed to have first accrued at the time of the dispossession or discontinuance of possession or at the last time at which any profits were so received.

The death of an owner in possession will also start the limitation period running. By section 20, those claiming against the owner's estate must bring action within ten years of the owner's death.

Other provisions of the Limitation of Actions Act will apply to postpone or extend the running of the limitation period. Where the owner is an infant or of unsound mind the right of action will not accrue until the owner ceases to be under said disability or dies, whichever happens first. ${ }^{31}$ However, section $46(3)$ does provide an outside limiting rule in such cases. Concealed fraud on the part of the adverse possessor, or a person through whom the adverse possessor claims will also postpone the running of the limitations period by section 31 until such "time at which the fraud was or with reasonable diligence might have been first known or discovered. ${ }^{132}$ Fraud is broadly interpreted; there must be an element of wrongdoing on the part of the adverse possessor as well as a special relationship between the adverse possessor and the owner. ${ }^{33}$ It is not concealed fraud where the adverse possessor pursues "a course of action calculated to be the least likely to alert the real owner to the fact of its possession. ${ }^{134}$ Sections 23 and 24 allow an extension where future estates are involved. Finally, where the owner is dispossessed while out of province, the owner is allowed to bring the action within two years of returning to Alberta under section $47 .^{35}$

Once the limitation period has begun, certain events require the adverse possessor to start over again towards the ten year period. One such event known at common law was the re-entry of the owner on the property for the purpose of taking possession. ${ }^{36}$ However, by section 43(1) of the Limitation of Actions Act, no person is "deemed to have been in possession of land within the meaning of the Act merely by reason of having made an entry thereon." It is up to the owner, therefore, to show evidence of clear acts intended to cast out the adverse possessor. It is sufficient if during the ten year period a certificate of title is issued in the name of the owner ${ }^{37}$ Further, to be effective re-entry by the owner must occur before the limitation period has expired. Re-entry once the

See Re Deal and Deal (1975), 50 D.L.R. (3d) 654 (Alta. S.C.T.D.), where the wife sought to establish adverse possession of the matrimonial home against her husband who was under a certificate of mental incompetence.

32. See also Twyford v. Bishopric (1914), 7 W.W.R. 102 (Alta. C.A.).

33. Revelstoke Cos. Lid. v. Lindsay (1981), 17 Alta. L.R. (2d) 339 (Q.B.). Where this special relationship exists it may also work against the owner's denying the adverse possessor's claim. See Zybriski v. Calgary (1965), 5 I D.L.R. (2d) 54 (Alta. Q.B.).

34. Revelstoke Cos. Lid. v. Lindsy, ibid. at 350 (Q.B.).

35. This section does not appear to have been argued in any of the adverse possession cases, although there was this potential in Revelstoke Cos. Lid. v. Lindsay, ibid. a case of an absentee land owner. However, section 47 does not refer to a person claiming through the owner, which perhaps is why it was not raised in Revelstoke, the owner himself being deceased.

3. Coope v. Hamilton (1881), 45 U.C.Q.B. 502 (C.A.).

37. Lutz v. Kawa, supra. note 2. The "owner" took over payments on the land and obtained title in her name seven years into the adverse possessor's limitation claim against her. This was held to stop the running of the limitation period. 
owner's title has been extinguished by section 44 of the Limitation of Actions Act, even if the adverse possessor has not taken further steps towards acquisition, will be ineffective unless the re-entry itself amounts to an adverse possession for a ten year period. This was the position adopted in Shirtcliffe v. Lemon, [1924] 1 W.W.R. 1059 (Alta S.C.) where the owner's two year dispossession of the adverse possessor, who previously asserted continual and uninterrupted possession for fifteen years, was not enough to defeat the adverse claim. As Simmons J. commented at 1062:

[The Land Titles Act] makes no provision for latent rights which may revive on the registered owner regaining possession. It would be a serious curtailment of The Statute of Limitations quite inconsistent with the apparent purpose and intent of the statute if the owner of an estate prior in time to the period in which the statute had run could destroy the statutory possession by regaining possession for any period less than the statutory one.

This statement also stands in opposition to the Alberta Institute of Law Research and Reform's proposal to do away with extinction of title by limitation. An owner whose title is extinguished stands as a stranger to the land.

The running of the limitation period also stops upon certain acts by the adverse possessor. Abandonment of the land by the adverse possessor is one such act. The logic is that in order to bring an action for recovery of land there must be someone in the position of defendant in relation to the plaintiff owner: "It is now elementary law that the statute does not run against a party out of possession unless there is a person in possession. ${ }^{138}$ If there is a lapse in possession by the adverse possessor, the owner's title reasserts itself. This is not to say that the adverse possessor must remain on the land continuously for the ten year period. Short breaks in possession will not stop the running of the limitation period. Which breaks in possession will or will not stop the limitation period depends on the circumstances. Where the adverse possessor retains control of the land as landlord there is no break in possession. ${ }^{39}$ In addition, as long as the interval between them is short, periods of adverse possession can be tacked together to fulfil the ten year requirement. For example, where B has occupied A's land for seven years and B in turn is displaced by $C$, the limitation period as against A expires three years after $C$ entered into possession. ${ }^{40}$ B has ten years from the dispossession to recover gains $C$. Although the adverse possessor remains in possession, the running of the limitation period will also be stopped by any acts which acknowledge the owner's title. Payments made to the owner under an agreement for sale recognize that true title lies with the owner. ${ }^{41}$ Similarly if the adverse possessor makes an offer to purchase the land, this restarts the

38. Handley v. Archibald, supra, note 34 at 137.

39. Nessman v. Bonke (1976), [1979] I W.W.R. 210 (Alta. S.C.T.D.).

40. Note that B will have a full ten years to recover possession as against $C$. This process of tacking where there is no privity between successive adverse possessors has been criticised by D.E. Armour, "Annotation" (1912) 8 D.L.R. 1021.

4l. Davis v. Brockway, [1949] 2 W.W.R. 1078 (Alta. S.C.). 
limitation period ${ }^{42}$ as would any payment that could be considered rent under a tenancy at will. $^{43}$

In addition, acts by a third party can wipe out the elapsed portion of the limitation period. When a third party obtains registered title to the property as a bona fide purchaser for value, the adverse possessor's claim is destroyed. This was first decided in Boyczuk v. Perry, [1948] 1 W.W.R. 495 (Alta. C.A.) and has been upheld in later cases. ${ }^{44}$ Mere knowledge of the adverse possessor's interest without more is not fraud so as to disqualify the purchaser as bona fide. ${ }^{45}$ Regardless of the length of time the adverse possessor has been in possession, failure to protect acquisition under the Land Titles Act, leaves the adverse title vulnerable to third party purchasers. However, the limitation period will continue where the third party takes the land as a volunteer, volunteers taking only as good a title as their predecessors. ${ }^{46}$

\section{Nature of Possession}

In addition to possession over time, adverse possession requires a certain quality of possession. The classic requirement is that the possession be "an actual possession, an occupation exclusive, continuous, open or visible and notorious ... [which] must not be equivocal, occasional, or for a special or temporary purpose. ${ }^{147}$ As this definition shows, the modern age no longer requires any form of hostility towards the interest of the owner as the word "adverse" implies. ${ }^{48}$ According to Laycraft, J.A. in Lutz v. Kawa at 278:

It seems quite clear that the modern use of the term "adverse possession" is to some extent a misnomer. The possession which now extinguishes title under the Limitations of Actions Act is different than the possession which was termed "adverse possession" prior to the Real Property Limitation Act, 1833 (U.K.), c. 27. Prior to that statute some possessions had been held to be "non-adverse."

Similarly, Feehan, J. in Zekonja v. Donald (1983), 50 A.R. 379 at 382 (Q.B.) stated, "there need not be an intent to eject or disentitle the true owner, so long as there is animus possidendi." And finally, Dobek v. Jennings, [1928] 1 W.W.R. 348 at 355 (Alta. C.A.), "there should be possession which implies ownership on the part of the possessor or the intention to own to the exclusion of any other person." Although both Zekonja v.

42. Dobek v. Jennings, supra, note 32, although adverse possession was not made out for other reasons.

43. Berube v. Cameron, [1946] S.C.R. 74. The majority of the court found that the payment of taxes by the adverse possessor constituted a payment of rent, thus there was no adverse possession.

4. Sinclair v. McLellan, [1919] 2 W.W.R. 782 (Alta. S.C.); Dobek v. Jennings, supra, note 32 [decided on other grounds]; Nessman v. Bonke, supra, note 44; Lutz v. Kawa, supra, note 2.

45. Hackworth v. Baker, [1936] 1 W.W.R. 321 (Sask C.A.); Nessman v. Bonke, ibid.

46. Kaup v. Imperial Oil Ltd., [1962] S.C.R. 170, 32 D.L.R. (2d) 112; Lutz v. Kawa, supra, note 2.

47. Sherven v. Pearson (1887), 14 S.C.R. 581 at 585. This definition is adopted in Lutz v. Kawa, ibid. and Tarcon v. Kerr (1981), 36 A.R. 282 (Q.B.).

4x. Thom's Canadian Torrens System, supra, note 30 at 191, outlines that previously there were five types of adverse possession: disseisin, abatement, intrusion, discontinuance, and deforcement all of which in one form or another involved some form of wrongful dispossession of the owner.

In light of Lutz v. Kawa, statements in Canada Permanent Trust Co. v. Herron, [1975] A.U.D. 338 (S.C.T.D.) requiring that possession be "adverse" must be considered over ruled. 
Donald and Dobek v. Jennings refer to the intention of the adverse possessor, there is no clear requirement of any subjective intention in Alberta. Elsewhere there has been much debate over whether subjective intent is necessary to quality of possession. ${ }^{49}$ But there is no attempt to pin down the adverse possessor's state of mind relevant to land occupied in Alberta. At most the courts look to an objective intention shown by the acts undertaken towards the land. Essentially the adverse possessor must establish possession of the land that is outwardly inconsistent with the notion of another holding title. This possession must be open so that the owner may know that title is being challenged and bring action for recovery. Two factors will affect whether or not the requisite quality of possession has been established - the relationship between the owner and the adverse possessor, and the nature of the acts undertaken with respect to the land.

Certain relationships by their nature preclude adverse possession. An example is joint tenancy. Under a joint tenancy the joint tenants have the same unity of possession, such possession preventing a claim in trespass by one joint tenant against another. Even where one joint tenant has been absent from the property for ten years the other cannot claim adverse possession, as was decided in Re Deal and Deal. Nor is adverse possession established where the owner continues to live with the adverse possessor on the property. In Brogden v. Brogden (1920), 53 D.L.R. 362 (Alta. C.A.) the son lived on, worked and improved land which he believed had been given to him by his mother. However, title to the land was actually held by his father. As the father had lived with the son for most of the limitation period, the son's possession was insufficient to destroy the father's right. ${ }^{50}$ Similarly in Dobek v. Jennings, the adverse possessor farmed the land with the knowledge and consent of the owner which prevented the possession from having the necessary character to extinguish the owner's title. Dobek v. Jennings also held that where the relationship between the owner and the adverse possessor is one of landlord and tenant there is no adverse possession as long as some form of rent is paid. The receipt of vegetables from the land and the payment of property taxes are two examples of what courts have held to be rent. ${ }^{51}$ If the adverse possessor is in default of the terms of the tenancy, possession can take on the necessary character to establish a claim to the land. ${ }^{52}$

Most often the determination of adverse possession claims will turn on the acts undertaken towards the land. Again it is difficult to state at the outset what acts will establish sufficient possession. Different types of land support different types of

D.E. Armour, "Title by Possession" (1921) 56 D.L.R. 135; M. Dockray, "Adverse Possession and Intention" (1982) 46 The Conveyancer and Property Law 256; R.H. Helmholz, "Adverse Possession and Subjective Intent" (1983) 61 Wash. University L. Q. 331. See also R.A. Cunningham "Discussion of Adverse Possession and Subjective Intent: a Reply to Professor Helmholz" (1986) 64 Washington University L. Q. 1 and R.H. Helmholz, "More on Subjective Intent: a Response to Professor Cunningham" (1986) 64 Washington University L. Q. 65. The dissent rejected the jury's finding and held that the claim of adverse possession could not be established. under $\mathbf{s .} 18$ of the Act." Numerous out of province cases have held this to be the case. 
possession. What is necessary to show possession of a narrow strip of an adjoining residential lot, will be different from that required with respect to an uncleared quarter section which in turn differs from that required for swamp land. This was clearly expressed by Lord Shaw in Kirby v. Cowderoy, [1912], 2 W.L.R. 723 (P.C.) at 726, cited in Duncan v. Joslin (1965), 51 W.W.R. 346 at 352 (Alta. C.A.):

Possession must be considered in every case with reference to the peculiar circumstances ... the character and value of the property, the suitable and natural mode of using it, the course of conduct which the proprietor might reasonably be expected to follow with a due regard to his own interests; all these things, greatly varying as they must under various conditions, are to be taken into account in determining the sufficiency of a possession.

The owner's plans for the land will also affect whether or not adverse possession has been established, as where the owner intends to hold land for later development. Possession by an adverse claimant is not inconsistent with the owner's title as the owner continues to use the land as intended.

Whatever else may qualify, acts undertaken in the belief, albeit mistaken, that title already lies with the adverse possessor are sufficient possession. It had been argued that a claim of adverse possession was inconsistent in such a situation but this issue was put to rest in Lutz v. Kawa (1980), 112 D.L.R. (3d) 271 at 280 (C.A.). Laycraft, J.A. stated "because he thinks the land is his own does not make his intention to possess less fierce, but probably the reverse." There have been several Alberta cases where adverse possession of the claimant's "own" land has been established. ${ }^{53}$ The counter to this is that merely holding registered title to land, is not possession of the land, especially where this "ownership" arises from a mistake in the certificate of title..$^{54}$

Whether the adverse possessor's acts show the necessary quality of possession is determined on a case by case basis. An exhaustive listing of what has and has not been enough to establish adverse possession in Alberta therefore would serve little purpose. However, some general comments can be made. Payment of property taxes may be evidence of sufficient possession, for example where the adverse possessor pays the taxes to avoid tax sale as in Revelstoke Cos. Ltd. v. Lindsay. On the other hand though, payment of taxes may be seen as the equivalent of rent thus continuing a tenancy, as noted earlier. ${ }^{55}$ In half of the Alberta cases the adverse possessor paid the taxes but there is no correlation between this and a successful action. Where the adverse possessor lives on the land or farms it this is usually sufficient. ${ }^{56}$ Lesser uses of land such as for

53. Re Anderton, supra, note 29; Saturley v. Young, [1945] 3 W.W.R. 110 (Alta. S.C.); Nessman v. Bonke, supra, note 44: Lutz v. Kawa, supra, note 2; Edwards v. Duborg, supra, note 25; Tarcon v. Kerr, supra, note 52, although the action may have failed for other reasons. Edwards v. Duborg, ibid.; Re Panther Resources Lid., [1984] 2 W.W.R. 247 (Alta. Q.B.). Berube v. Cameron, supra, note 48.

Re Anderton, supra, note 29; Harris v. Keith (1911), 16 W.L.R. 433, 3 Alta L.R. 222 (Alta. S.C.); Wallace v. Potter (1913), 4 W.W.R. 738 (Alta. S.C.); Shirtcliffe v. Lemon, [1924] I W.W.R. 1059 (Alta. S.C.). 
storage of equipment or merely as pasturage are often not enough. ${ }^{57}$ Fencing or repairing fences is also good evidence of adverse possession. ${ }^{58}$

The nature of the acts supporting adverse possession will also determine the extent of the land subject to the claim. The owner of land is presumed to have constructive possession of the whole property unless it is shown otherwise. As a result, the adverse possessor can only acquire that portion of the land over which sufficient possession is actually exercised. ${ }^{59}$ This is summarized in Zekonja v. Donald at 383:

Thus, it is clear that the act or series of acts must be such as to amount to a continuing announcement of the intent to possess and must extend to all of the land being claimed. If the act or intent extends only to a portion of the land, then the adverse possessor can only lay claim to that portion.

A good illustration is the case of Harris v. Keith, above. The adverse possessor used portions of the land in question for different purposes. The court found that where he had fenced, ploughed and cultivated the land, he had a valid claim. However, he was not entitled to that portion of the land which he had simply maintained as pasture, allowing others' animals onto it as well. Similarly in Zekonja v. Donald, the adverse possessor's house extending onto the neighbouring vacant lot entitled the adverse possessor to the overlap plus a four foot strip, but mowing the lawn and storing equipment did not show possession of the rest of the lot.

\section{B. CURRENT LAW OF ACQUISITION}

\section{Bringing Adverse Title Under the Torrens System}

Once the owner's title is extinguished by adverse possession, the logical result is that title should pass to the adverse possessor: ${ }^{.0}$

On the whole it seems to me that the balance of opinion and practice is very strongly in favour of the doctrine that a title in fee simple, or what we should consider equivalent thereto, can be acquired, not indeed by virtue of any express words contained in the statute, but as a logical consequence of the effect resulting from its operation.... Assuming that the real owner, that is, the holder of the paper title, or his

Storage of equipment: Sinclair v. McLellan, supra, note 49; Cf. Zekonja v. Donald (1983), 50 A.R. 379 (Q.B.). Pasturage: Harris v. Keith, ibid. 3 Alta L.R. 222 (Alta. S.C.). Also Tarcon v. Kerr. supra, note 52, where pasturing by the owner was inadequate to displace the adverse possessor. Wallace v. Potter, supra, note 61: Shirtcliffe v. Lemon, supra, note 61; Dobek v. Jennings, supra, note 32; Lutz v. Kawa, supra, note 2.

McConaghy v. Denmark, 4 S.C.R. 609.

Re Anderton supra, note 29 at 333 (Alta. S.C.). The judge stated of other Torrens jurisdictions at 330:

I find also that in the different States of Australia, where the Torrens system prevail, applications are constantly made to bring land under the Act and for the issue of a certificate upon the basis of a mere possessory title, and that such applications are granted and certificates issued not only in those States whose Land Titles Acts contain special clauses dealing with the rights of persons claiming by possession and permitting them to secure registration, but also in those States whose Acts, like our own, do not contain any specific reference to the question. 
representative is known, and that he is barred, the possessor's title seems to me to become full grown and complete. No one in the world can ever disturb him.

This is acquisition by the common law. The adverse possessor holds the fee simple from the first day of possession, although the claim may be defeated by the paper owner before the limitation period expires. ${ }^{61}$ Harris v. Keith held that the Torrens system had not altered the nature of the estate acquired by adverse possession. Harris v. Keith and another early Alberta case, Wallace v. Potter, adopt the position arrived at in Belize Estate and Produce Co. Ltd. v. Quilter (1897) A.C. 367 (P.C.) that a registered certificate of title to land under the Torrens system does not prevent the land being acquired through adverse possession. Concerning the interaction of the Land Titles and Limitation Acts, Simmons J. had this to say in Wallace v. Potter at 739:

It is not disputed that the terms of The Limitation Act if taken alone are sufficient to include and apply to all lands in the Province of Alberta. Our [Land Titles Act]... contains no provision which expressly exempts lands held under a registered titles from the operation of The Limitation Act.

The more recent case of Lutz v. Kawa comes to the same conclusion at 277: "Section [74] must be taken as an additional exception to the six exceptions to indefeasibility of title set forth in s. 180 of the Land Titles Act."

However, although title by adverse possession was sufficient to bring land under the Land Titles Act, as was held in Re Anderton, the courts were powerless to correct an existing certificate of title, even though a declaratory judgment showed the adverse possessor as entitled to the land. This was the situation in Wallace v. Potter. ${ }^{62}$ The owner's title had been extinguished in favour of the adverse possessor but there was no provision in the Land Titles Act to amend the certificate of title, as the judge pointed out at 741:

\begin{abstract}
...no provision has been made for enabling a person who has been in adverse possession for the statutory period to put upon the register an entry of any rights or interest which he may thereby have acquired.... The result is that the plaintiff has acquired a title to the land which cannot be attacked by the person actually registered as the owner and in whose name a certificate of title is not upon the register. The result is quite an anomalous one but the authority for removing the anomaly is in the legislature and not in the courts.
\end{abstract}

The situation described here by Simmons J. re-introduces uncertainty of the kind the Torrens system was designed to prevent. Such uncertainty is inconsistent with Torrens principles. The Torrens system aims to protect the owner of the fee simple to the land through the process of registration. Here was a situation of an owner in fee simple who could not register under the Land Titles Act.

61. Wheeler v. Baldwin (1934), 52 C.L.R. 609.

o2. Wallace v. Potter was the first case to raise the issue of changing the existing certificate of title in favour of the adverse possessor. The adverse possessor in Harris v. Keith, supra, note 61, had not asked for a declaration that the owner's title had been extinguished. 
The legislative changes called for by Simmons J. were enacted in 1921 by An Act to Amend the Land Titles Act, S.A. 1921, c. 39, s. 2. This amendment to the Land Titles $A c t$, now section 74, is discussed above. It allows the adverse possessor to obtain title within the Torrens system as well, thereby gaining its protection and providing notice to others. The amendment also ended debate over whether Belize Estate and Produce Co. Ltd. v. Quilter had properly been adopted in Alberta. According to Laycraft. J.A., speaking in Lutz v. Kawa at 277:

\begin{abstract}
Whether or not Belize Estate and Produce Co. Lid. v. Quilter was wrongly applied to the Alberta Torrens statute is now beside the point. The Legislature has recognized and adopted that statement of law when it enacted a procedure to obtain title after a declaratory judgment for adverse possession. Despite its incompatibility with the pure theory of a Torrens statute, adverse possession is here to stay unless there is a change of policy by the Legislature.
\end{abstract}

The inconsistency between adverse possession and the Torrens system was resolved in Alberta, not by abolishing adverse possession, but by accommodating it within the Torrens system. This is further evidence that in Alberta adverse possession still plays a valid role in land holding.

\title{
2. Failure to Protect Title by Registration
}

The full benefits of the acquisitive principle are not automatic. Section 74 requires the adverse possessor to obtain a declaratory judgment on the adverse claim and to file a copy of the judgment in order to have a certificate of title issued. Failure to take positive steps to protect adversely acquired title leaves it highly defeasible. For example, the adverse possessor without a certificate of title risks losing title by abandoning the land, as happened in Sinclair v. McLellan. Walsh J. hesitantly found that there had been possession of the land for the limitation period; however, the adverse possessor had vacated the land. She later sought to enforce her claim against a successor to the registered owner but was refused as. To allow her claim would "seriously detract from the value of a certificate of title." ${ }^{163}$ Walsh J. further illustrated the problem in stating at 788:

It would simply mean that a man buying land must satisfy himself not only that his vendor is the registered owner, but also that his title has not been extinguished by a possessory title acquired by someone else who after acquiring it vacated the premises and without protecting as he might his claim to or interest in the land by the registration of a caveat, set himself up as the absolute owner of it by virtue of his former possession.

Indeed this would be a serious step backwards, to the period even before the first limitations legislation, where priority would go to the person who could show prior possession and thus better seisin. 
Unregistered title by adverse possession will also be lost to a hona fide purchaser for value. ${ }^{6 t}$ In Nessman v. Bonke, the adverse possessor had taken no steps to protect her title, as she believed she was the registered owner. Unfortunately, her title was actually to the adjoining lot. Although adverse possession had been established for a continuous period of thirty years, bona fide purchasers twice destroyed the adverse title. As the judge stated at 213-14:

The Land Titles Act does prevail over a person who has got that title by adverse possession because the adverse possessor's title is not registered. Once a person acquires adverse possession, or title by adverse possession. and has served ten years on the property, he must take proceedings to get his title quieted and registered pursuant to the Act and if he does not he has not got a registered interest. And where there is a title to land registered in $A$ and an adverse possessor on that land, if $A$ sells his land to $B$ and $B$ gets in his title, that destroys the title of the person who has adverse possession.

It was irrelevant that the last bona fide purchaser in Nessman v. Bonke had notice of the adverse interest as there had been no fraud on the purchaser's part. The Land Titles Act will protect the third party unless the third party acts fraudulently. Mere notice is not fraud, as the Land Titles Act sets out in section 195. Although the owner's title has been extinguished it can give root to a valid title in the hands of a bona fide purchaser for value. This was the result in Lutz v. Kawa, supra, note 2 at 286 (C.A.):

The literal wording of s. 44 of the Limitation of Actions ACt is that at the end of the 10-year period limited for the recovery of land, the right to recover is extinguished. Notwithstanding this provision it is clear that such a title, after it is "extinguished," may become the root of a valid title in the hands of a bona fide purchaser for value.

This was the result in as mentioned, a third party volunteer will not destroy the adverse possession though as the volunteer's title is only as good as the owner's.

\section{Improvements to Land}

Section 60 of the Law of Property Act addresses this problem of the intervening bona fide purchaser. Section 60 appears to be a legislative response to the situation in Boyczuk v. Perry. Commenting on what he saw as a defect in the then existing system of adverse possession, O'Connor J.A. had the following to say at 417-18:

Many large buildings have been erected in Alberta cities on sites surveyed by local surveyors. Some of these surveyors are dead. Others are very old. It is highly probable that new surveys would show that many walls are encroaching on adjacent land.

The Limitation of Actions Act was designed to protect inter alia the owners in such a case but if an intervening certificate of title is an answer to the Limitation of Actions Act in a case where the transferor did not intend to sell or the transferee intend to buy the encroaching wall, that is, where there is a mutual mistake or a wrong description of boundaries or parcels included in the certificate of title then no property 
owner is safe. because the intervening certificate of titles may be readily and legally procured by an unscrupulous owner.

Thus it was seen as unjust in certain circumstances to allow the defeat of an established adverse title by an intervening certificate of title, especially where the "adverse possessor" had no reason to question the title or to have it quieted. Section 60 provides a means to avoid this. Although it remained unused for its first quarter century of existence, section 60 has become "a statutory exception to what appears to be the whole system of the Land Titles Act." ${ }^{.55}$ Strictly speaking section 60 is not an action in adverse possession. There is no limitation period involved. In fact the action under section 60 can be brought in relation to improvements made "at any time." ${ }^{66}$ Unfortunately, the Alberta Institute of Law Research and Reform in Report 55 advocates placing section 60 under the fifteen year ultimate rule in its proposed legislation. Neither is possession mentioned in section 60 but it can be inferred. How could you make improvements to land in the belief that it is your own, without being in possession and undertaking acts indicative of possession? Section 60 provides a back gate for the adverse possessor to regain the land.

Section 60 sets out two requirements. First the adverse possessor must show that lasting improvements have been made on the land in question. Mildenburger v. Prpic, [1976] 4 W.W.R. 67 was the first case to consider the section. McDonald, J. defined "lasting" as not being easily removable and "improvement" as "an addition to property amounting to more than a mere replacement of waste" whether or not it enhanced the value of the land. Several cases have held that clearing land for farming or development qualifies as a lasting improvement. The improvements need not have been made by the adverse possessor. The adverse possessor can claim as an assignee of the person who made the improvements.

The second requirement of section 60 is that the person making the improvements must believe the land was his or her own. Mildenburger v. Prpic notes that no distinction is made between mistakes as to title and mistakes as to identity. The belief must be honestly held, reasonableness going to determine honesty. ${ }^{67}$ Where the claimant fails to make inquiries warranted in the circumstances there is not honest belief. ${ }^{68}$ Likewise where the adverse possessor knows another holds title to the land. ${ }^{69}$ Unfortunately, the required belief is not present where the improvements were made by a person who did own the land. In Nessman v. Bonke, the improvements were made on one of two parcels

Nessman v. Bonke, supra, note 44 at 218. Section 60, then section 173 of the Land Tilles Act, was first interpreted in Mildenburger v. Prpic, [1976] 4 W.W.R. 67, 67 D.L.R (3d) 65 (Alta. T.D.). The section was previously raised in Nova Holding Ltd. v. Western Factors Lid. (1965), 51 W.W.R. 385 but not subject to judicial comment.

W.H. Hurlburt suggests in "Improvements Under Mistake of Ownership: Section 183 of the Land Title Act" (1978) 16 Alta. L. Rev. 107 at 115 that "|t|he imposition of a limitation period would go a long way towards defeating the purpose of section [60], as by its very nature it applies in cases of mistake in which the error may be undetected for many years." Mund v. Medicine Hat (1988), 59 Alta. L.R. (2d) 199 at 205.

6*. Maly v. Ukrainian Catholic Episcopal Corp. (1976), 70 D.L.R. (3d) 69I, I Alta. L.R. (2d) 277 (Dist. Ct); Canada Permanent Trust Co. v. Herron, supra, note 53. 
of land when both parcels were owned by the same person. These improvements did not fall within section 60 to the benefit of later assignees of the property. Steer J. found at 218 that section 60 "requires someone to make an improvement on property that is not his own in the belief that it is his own." To adopt the same reasoning used in Lutz v. Kawa, actual ownership will not discredit a belief that one owns the land. This view enhances the usefulness of section 60 . But even by its narrow interpretation, the existence of section 60 witnesses that adverse possession is alive and well in Alberta and the legislative efforts to keep it that way.

\section{SPECIAL CASES}

\section{Land Not Under the Torrens System}

Land not subject to the Torrens system of registration is still governed by the common law and thus subject to adverse possession. This was the position taken in Re Anderton, one of the earliest Alberta cases. Anderton had shown sufficient possession of nonTorrens land to establish registrable title by adverse possession. The Land Titles Act permits registration of adversely acquired title:

36(1) The Owner of any estate or interest in any land whether legal or equitable, letters patent for which issued from the Crown before January 1, 1887, or that otherwise had prior to that date passed from the Crown, may apply to have his title registered under this Act. [emphasis added]

"Owner" is defined in section 2 as "a person entitled to any freehold or other estate or interest in land, at law or in equity, in possession, in futurity or expectancy" and is wide enough to cover interests acquired by adverse possession. However, there remains little private land in the province which has not been brought under the Torrens system. Most land for which no certificate of title has been issued is Crown land which is not subject to adverse possession.

Crown and public lands are immune to claims in adverse possession by virtue of section 4 of the Public Lands Act, R.S.A. 1980, c. P-30:

4. No person may acquire by prescription an estate or interest in public land or, as against the Crown, in any other land.

The rationale is twofold. Crown and public lands are held for the benefit of all citizens and it would be unjust for one to deprive all of part of this benefit. Secondly, given the vast acreage of such land it is impossible to patrol against adverse possessors. Similar protection is extended to municipal lands in section 437 of the Municipal Government Act, R.S.A. 1980, c. M-26:

437. No person shall by reason of the adverse or unauthorized possession, occupation, enjoyment or use of any land owned by the municipality ... obtain any estate or interest therein or in any such land by reason of the adverse possession, occupation, enjoyment or use thereof, and it shall be deemed that no such right has heretofore been so acquired. 
The courts readily accept such statutory provisions in defence to an action in adverse possession. Nor are such provisions in contravention of equality rights under section 15 of the Canadian Charter of Rights and Freedoms. ${ }^{70}$ Section 14 does not contemplate Crown or municipalities. However, a municipality may not be able to rely on the protection of section 437 where it stands in fiduciary relationship to the adverse possessor and acts fraudulently in breach of this obligation. Such was the case in Zybriski v. Calgary, where the city had offered to help the adverse possessor obtaining title to the land and then had itself registered as the owner. Zybriski v. Calgary may also stand for the proposition that a municipality will be unable to deny title to the adverse possessor where it has assessed the adverse possessor as owner of the land for a period of years and has collected the taxes.

\section{Mines and Minerals}

Just as adverse possession to land not already under the Torrens system is a rare occurrence, so is a claim of adverse possession of mines and mineral. As with non-Torren land, unpatented mines and minerals belong to the Crown. ${ }^{71}$ This is reflected in sections 10 and 43 of Mines and Minerals Act, R.S.A. 1980, c. M-15, and the Crown cannot be adversely possessed. There are, however, also privately held titles to mines and minerals. Private mines and minerals can be acquired by adverse possession and several actions have been attempted. The problem lies in determining what is sufficient possession. As was discussed in Re Panther Resources Ltd. at 261 (Alta. Q.B.):

It is conceivable that mines and minerals may be adversely possessed; however, to establish same would requires "actual occupation, exclusive, continuous, open or visible and notorious for 10 years" in a manner suitable to the nature of the property.

No Alberta case has found such possession and declared adverse title to mines and minerals. However, certain acts are insufficient to establish possession. Merely holding title does not establish possession. ${ }^{72}$ Nor does the granting of a lease over the mines and minerals, ${ }^{73}$ or payment of the mineral taxes. ${ }^{74}$ At minimum possession requires some evidence of drilling or other acts consistent with the possession of the mines and minerals. Drilling for seismic tests will not qualify. ${ }^{75}$

\section{JUSTIFICATION OF ADVERSE POSSESSION}

\section{A. CONSISTENCY WITH THE TORRENS SYSTEM}

Canadian Charter of Rights and Freedoms, Part I of the Constitution Act, 1982, being Schedule B of the Canada Act 1982 (U.K.), 1982. c. I1. See Mund v. Medicine Hat, ibid.

Order in Council P.C. No. 2167 (Sept 17, 1989).

Re Panther Resources Lid., supra, note 59.

Re Panther Resources Lid., ibid.; Duncan v. Joslin (1965), 51 W.W.R. 346 (Alta. C.A.).

Duncan v. Joslin, ibid.

Duncan v. Joslin, ibid. 
Both case law and academic writing have stated that adverse possession is inconsistent with the Torrens system. Harvey C.J.A. in Dobek v. Jennings at 350 felt that extinguishing of the owner's rights after the running of the limitation period was "not in entire harmony with our Torrens system under which titles can only be extinguished by registration." He further questioned the constitutionality of An Ordinance Respecting the Limitation of Actions Relating to Real Property, O.N.W.T. 1893, no. 28, which gave effect to The Real Property Limitation Act, 1874, as in his opinion it derogated from the rights conferred by the federal Land Titles Act. Alberta's embracing of adverse possession has also been criticised by Professor Williams who finds that adverse possession hinders reliance on the certificate of title. ${ }^{76}$ Indeed the very fact that all other Canadian Torrens jurisdictions have virtually legislated adverse possession out of existence speaks against their coexistence.

Arguably, adverse possession is contrary to several basic components of a Torrens system. Adverse possession weakens the basic declaration of indefeasibility set out in section 64 of the Land Titles Act. By allowing adverse possession, the owner no longer holds land absolutely free from encumbrances, liens, estates and interests not endorsed on the certificate of title. Not only can the adverse possessor encumber the owner's title but he can make it defeasible as well. Similarly, a Torrens system envisages all interests in land clearly shown on the certificate of title. Rarely will an adverse interest be registered or caveated against title before the expiry of the limitation period as this would alert the owner to the claim. Notice of any caveat must be sent to the registered owner by section 134 of the Land Titles Act. Further, adverse possession works around the evidentiary effect of a certificate of title. Section 66 states that a certificate of title is conclusive proof in all courts that the person indicated on the certificate is entitled to the land. This is clearly not the case where the owner's title has been extinguished but the adverse possessor has not as yet had the certificate of title changed. Another basic Torrens principle, supported in sections 160 and 173, is that the owner is not subject to ejectment. What is the effect of adverse possession, if not ejectment? Adverse possession therefore strikes at the roof of the Torrens system. Admittedly, all of the above sections are subject to certain express exceptions set out in the Land Titles Act; however, adverse possession is not listed among them.

In answer to these complaints of inconsistency recall why the Torrens system developed and what its basic purpose is. Against this backdrop adverse possession is not inconsistent. Sir Robert Torrens was firmly roused against the English system of land holding by a friend's loss of an estate, including $£ 20,000$ spent on improvements. ${ }^{77}$ The loss was caused by an equitable right of which the purchaser was deemed to have notice. Torrens' experience in the area of shipping titles convinced him there could be a system of land holding in which transfers could be easily effected, all interests and encumbrances being noted. A purchaser would thus be free of any unindicated detrimental interests and could rely on a good transfer from the vendor. The problems a Torrens system aims to solve, therefore, are primarily of a transfer or conveyancing nature. The protection of the

77. R.W. White, "The Elements of a Torrens Title" (1973) 11 Alta. L. Rev. 392 at 395. 
bona fide purchaser for value is the Torrens keystone. The owner of land is not protected qua owner of land but because of reliance on a transfer for value from the predecessor. Certain transfers, however, cannot be relied on, and do not convey indefeasibility. For example, where there is a prior certificate of title, two chains of ownership develop, one of which must logically be invalid. Transfers along the invalid chain cannot be relied on and will never give root to a good title. Misdescription is another absolute exception to indefeasibility provided for in the Land Titles Act. In other cases only a single transfer in the chain may be tainted. Only the tainted transfer cannot be relied on, transfers further along the chain passing good title. For example, a bona fide purchaser can take good title from a predecessor who gained title fraudulently, as long as the purchaser's title does not become tainted by participation in the fraud. Likewise, volunteers and adverse possessors cannot rely on their transfers as they have not given value for them. ${ }^{78}$ They will take only what the owner had. Adverse possession will only be inconsistent with the Torrens system if it interferes with bona fide transfers for value. Adverse possession operates exclusively between the owner and the adverse possessor. Any bona fide purchaser for value coming into the picture will be protected. Where a bona fide purchaser for value obtains a transfer of the property from the owner, the limitation period begins afresh, any claim of the adverse possessor being wiped away. ${ }^{79}$ Even where the owner transfers an extinguished title it will serve as the root of a good title where there is a transfer to a bona fide purchaser for value. ${ }^{80}$ Adverse possession does not prevent reliance on transfers for value and does not prejudice bona fide purchasers. There is no inconsistency between adverse possession and the Torrens system.

\section{B. THE ROLE OF ADVERSE POSSESSION}

Consistency with the prevailing system alone is not enough to justify a law's continuation. The law must serve some purpose in its own right. It is a basic notion of our legal system that one cannot benefit from one's own wrong. This is not upheld in adverse possession. From the outset, the adverse possessor is a trespasser to the land. Continuation of this tortious conduct long enough is rewarded in our system by granting the adverse possessor title to the land. The original owner then becomes the trespasser. As stated by H.W. Wilkinson in "Adverse Possession - Starting and Stopping" (1988) 138 New L.J. 238 at 238, "...the obtaining of a title to land by adverse possession may be regarded as [one] of the few ways in which the enterprising citizen may lawfully 'steal' something." That adverse possession has operated as an exception to natural justice for so long shows that there must be other factors that weigh in its favour, some other purpose it serves.

Several policy reasons speak in favour of adverse possession. These reasons are strong and balance out the perceived injustice caused by allowing the adverse possessor to 
benefit from wrongdoing. Adverse possession is traditionally justified on four grounds. These are best described by Elfant: ${ }^{81}$

The doctrine is designed to remove clouds on title by serving four underlying and interrelated purposes: first, it prohibits stale claims brought by the original owner; second, it grants repose to the adverse possessor, third, it encourages the development of otherwise idle property; and finally, it grants title in the equitable owner of the land.

Of the four purposes served by the doctrine, two are directly tied to the statute of limitation: the elimination of stale claims brought by the original owner, and the granting of repose to the adverse possessor.... The other two purposes served by the doctrine of adverse possession - the development of otherwise idle property and the quieting of title in the equitable owner of the land - derive from the principles of economic efficiency and faimess.

Both the repose of the adverse possessor and the granting of title can be seen as derive from the extinction of stale claims. Extinction of stale claims is likely the reason that speaks loudest in favour of adverse possession. Most causes of action are restricted by limitation periods and the recovery of land should be no different. ${ }^{82}$ It is also to be noted that recovery of land enjoys one of the longest limitation periods. Given a stale claim it is just that fresh title fall to the person exercising the rights over land that come with ownership - the adverse possessor. Under a Torrens system the holder of title must be recorded in the registry thus the third reason, the quieting of title in the adverse possessor, is also essential.

The resulting justice of the first two reasons is easily seen in three Alberta cases. In Wallace v. Potter, Wallace began occupation of Potter's land fifteen years after Potter abandoned it. Wallace erected substantial buildings, cultivated thirty acres and made significant improvements to the property. After thirteen years in possession of the land, Wallace applied for a declaration that he was the owner of the land and the action proceeded in default. Sympathy clearly rests with Wallace and the court had no hesitation in granting the declaration. In Saturley v. Young, an adverse possessor for twenty-eight years was awarded title to the land as the owner was held to be a missing person. The out of province owner in Revelstoke Cos. v. Lindsay obtained registered title to the lands in 1923. The court found the owner had forgotten about these properties, most of which had reverted to the municipality under the Tax Recovery Act, the unexplained exception being the lands adversely possessed by the plaintiff. Fifty-eight years of non-use of the lands by the owner was more than sufficient for the court to find the adverse possessor entitled to title. In the above cases, were it not for a process of divesting the owner of title, land would become sterilized. The owner's certificate of title would impair any

kI. N. Elfant, "Compensation for the Involuntary Transfer of Property Between Private Partics: Application of a Liability Rule to the Law of Adverse Possession" (1984) 79 Northwestem University L. Rev. 758 at 758 and 760 .

x2. Arguably, a pressing concem with stale claims is the problem of proof which is largely eliminated by Torrens registration and a certificate of title. See Land Titles Act, s. 66. 
transfer of land which the owner had no intention of using. It does not shock our principles of justice and morality that this land should be available for use to someone else and its transferability re-established.

Before discussing the rationale that adverse possession leads to the efficient use of land there are a few reasons, other than those traditionally advanced, justifying adverse possession that merit mention. First, adverse possession supports the link between possession and ownership that has always been central to other notions of land holding. Second, adverse possession is a means of boundary rectification between adjoining parcels. Early survey technology was not always adequate and buildings were often placed by eye measure. Adverse possession can render de facto boundaries into de jure ones. Third, the issuing of a new certificate of title to the adverse possessor, especially where the old owner cannot be found, will favour certainty in transfers. Although the adverse possessor's title is more easily defeasible and subject to unregistered interests the adverse possessor will be able to pass a good root of title to a bona fide purchaser for value, thereby eliminating the binding effect of any unregistered interests. Certainty of title increases the value of land. Fourth, adverse possession avoids problems encountered in other Torrens jurisdictions. For example, in Saskatchewan, situations arise in which title to land hangs in limbo with no means of resolution. Under an agreement for sale that is not fully executed before the expiry of the vendor's right to recover land, the purchaser has no means to obtain clear title to the land where the vendor has disappeared or died leaving no heirs. ${ }^{83}$ The same situation arises in respect of a mortgagee and mortgagor. In Alberta, this situation does not arise as the purchaser or mortgagee will be able to clear title by showing adverse possession. Finally, title by adverse possession ascertains who should be liable to assessment for property taxes. Adverse possession in the modern context does serve a greater purpose than a reminder of quaint feudal notions of land holding. As Professor Goodman has mentioned, "Acquisition of title by adverse possession is not immoral and can have a benign influence on the social policy that security should be given to the long possessor of the land." ${ }^{14}$

\section{POTENTIAL FOR REFORM}

The "development of otherwise idle property" is one of the traditional justifications for adverse possession. Its analysis may also be the key to reform. The adverse possessor is considered as making more efficient use of the property than the owner who, by definition, is doing nothing with the land. According to Professor Williams this "ensure[s] that land shall be used in a way beneficial to the community." ${ }^{55}$ However, as the law of adverse possession currently presumes that any use by the adverse possessor is most efficient and thus of higher value than the non-use of owner. This may be true of an agrarian society where most production is land dependant. But as society shifts from agrarian to industrial to service based, the possible and necessary uses of land change. In light of environmental concerns, the value of land preserved in its natural unused state 
may even exceed the most efficiency developed use. The presumption that any use is better than no use is no longer valid. To bring the law back in step with the rationale the presumption must be discarded and a new means of establishing economic efficiency developed.

Elfant proposes a system which better serves the aim of adverse possession to promote economic efficiency in land. ${ }^{86}$ Elfant invokes the economic theory of Professors Calabresi and Melamed and proposes a liability rule for adverse possession, such as has been applied in the law of nuisance. Under such a rule the adverse possessor would be able to destroy the owner's entitlement to the land but with compensation for the owner's loss. This would require an economic analysis of the adverse possessor's and the owner's uses of land in considering any adverse claims. ${ }^{87}$ For example, if the land is worth $\$ 10,000$ / hectare by the adverse possessor's use and only $\$ 5,000 /$ hectare by the owner's use, economic efficiency of the land favours transfer to the adverse possessor, whose title is being worth double that of the owner. This is in line with the traditional presumption in favour of use by the adverse possessor. If, however, the reverse were true the land valued by the owner at $\$ 10,000 /$ hectare but only $\$ 5,000 /$ hectare by the adverse possessor, the land is devalued by transfer to the adverse possessor. In this case, efficiency is promoted by leaving the land with the owner. The value of non-traditional uses of land, such as presentation or speculation, can also be considered in valuing competing uses of the land.

Elfant would enforce the more efficient use by requiring the adverse possessor to compensate the owner for loss incurred in the transfer of the land. This also minimizes the negative perception of adverse possession as theft of land. In the first example above, giving title to the land to the adverse possessor would mean a loss in value to the owner of $\$ 5,000 /$ hectare. This is the price the adverse possessor should pay in compensation. The adverse possessor benefits by acquiring land for half of its perceived value. In the second example, if the adverse possessor values the land at $\$ 5,000 /$ hectare, yet must compensate the owner's at $\$ 10,000$ / hectare, the adverse possessor will forfeit possession in favour of the owner's title. Under a Torrens system, payment of compensation to the land owner makes the adverse possessor a purchaser for value, not a volunteer. The resulting title would therefore be indefeasible against non-registered interests.

86.

N. Elfant, "Compensation for the Involuntary Transfer of Property Between Private Parties: Application of a Liability Rule to the Law of Adverse Possession" (1984) 79 Northwestem University L. Rev. 758.

87. Elfant's approach is a utilitarian one as it recognises that under certain market conditions forced exchanges for compensation may be required in response to high transaction costs. A libertarian system would oppose such exchanges. It is not the purpose of this paper to analyze adverse possession from the libertarian and utilitarian perspectives as this has been exhausted in a series of articles: Epstein, R.A., "Past and Future: The Temporal Dimension in the Law of Property" (1986) 64 Wash. University L. Q. 667: Ellickson, R.C., "Adverse Possession and Perpetuities Law: Two Dents in the Libertarian Model of Property Rights" (1986) 64 Wash University L. Q. 723; Radin, M.J., "Time Possession and Alienation" (1986) 64 Wash University L. Q. 739; Rowley. C.K., "The Law of Property in Virginia School Perspective" (1986) 64 Wash. University L. Q. 759; Haddock. D.D., "First Possession Versus Optimal Timing: Limiting the Dissipation of Economic Value" (1986) 64 Wash. Universily L. Q. 775. 
Consideration of the value of land, as Elfant suggests, would be a useful reform in the area of adverse possession law. The shell of such a system is already in place in section 60 of the Law of Property Act. For convenience the section is repeated.

60(1) When a person at any time has made lasting improvements on land under the belief that the land was his own, he or his assigns

(a) are entitled to a lien on the land to the extent of the amount by which the value of the land is enhanced by the improvements, or

(b) are entitled to or may be required to retain the land if the Court is of the opinion or requires that this should be done having regard to what is just under all circumstances of the case.

(2) The person entitled or required to retain the land shall pay any compensation that the Court may direct.

The section is not restricted to an application by the adverse possessor only. The wording is broad enough to support an application by the owner: "When a person at any time has made lasting improvement on land under the belief that the land was his own, he or his assigns... may be required to retain the land... [and] shall pay any compensation that the Court may direct." Section 60 should be pleaded in the alternative to both claims of adverse possession and recovery of land. Lutz v. Kawa made it express that there is no prohibition against such alternative pleas. Pleading section 60 in adverse possession saves the time and cost of having to bring a separate action under section 60 should the claim in adverse possession fail, as happened in Lutz v. Kawa. Pleading section 60 in recovery of land removes the risk of the owner losing title to land without compensation. Adding the element of compensation at the discretion of the court removes the bad taste of adverse possession. The adverse possessor would no longer get something for nothing, no "free" land. The owner would be compensated for loss of rights.

Sections 60(1)(b) and 60(2) serve as the basis for adopting the Elfant system. Section 60 (1)(b) leaves the Court considerable discretion in deciding who the land will rest with. Section 60(2) gives discretion as to what compensation should pass. Further, 60(1)(a) prevents the owner being enriched by any improvements the adverse possessor had made. Section 60 is not without shortfall though. Section 60 does not provide for the adverse possessor who improves land knowing title to be with another. To this extent, section 60 distinguishes between adverse possessors on the basis of state of mind at the start of possession. This is inconsistent with the overall view of adverse possession in Alberta as not requiring subjective intent. Section 60 should be amended to strike the words "under the belief that the land was his own." Such an amendment would better reflect our law of adverse possession. It would also increase the usefulness of section 60. Most significantly, an amended section 60 would prevent a third party unjustly defeating the adverse possessor. As the law stands, a third party can knowingly defeat the adverse possessor's claim by obtaining title from the paper owner. If the adverse possessor could claim under section 60 , there would be an opportunity to legitimize the adverse title through compensation to the third party. The priority contest would therefore be between the adverse possessor and the third party. This is not contrary to the Torrens system of reliance on the registry. The third party would lose title only where the adverse possessor's value of the land is greater. The third party would also receive compensation. 


\section{CONCLUSION}

Adverse possession is alive and well in Alberta. The Land Titles Act has been particularly responsive to problem situations as they have arisen and amendments have been made which entrench the law of adverse possession within the Alberta Torrens system. Section 74 allows a certificate of title to be corrected to reflect a transfer of title by adverse possession. Relief is also provided for the failed claim by section 60 of the Law of Property Act. The Alberta law is consistent with Torrens principles - bona fide purchasers for value are not prejudiced by adverse claims. No title to land is ever completely indefeasible and the Land Titles Act provides several instances where the owner may lose title. Adverse possession is but one of them.

Recommendations of the Alberta Institute of Law Research and Reform, both in regard to the reform of limitations legislation and specifically in regard to adverse possession indicate that the days of adverse possession may be numbered. Abolishing adverse possession would be an unfortunate occurrence. Adverse possession serves a valuable purpose in extinguishing stale claims and making more efficient use of land. It can also be a useful tool for rectifying mistaken boundaries between adjoining parcels. Adverse possession promotes title certainty, transferability, and value maximization of land.

The remaining problems are not resolved by abolishing the entire law of adverse possession. Constructive reform is the solution. The law should provide a method of compensation to the owner or third party who suffers a loss as a result of the adverse possessor's successful claim. This addresses the concern that the adverse possessor gets an unjust benefit from trespassing, and the problem of the third party defeating the adverse possessor's claim. Setting the level of compensation at the value of the loss also favours the economic efficiency of land. Section 60 of the Law of Property Act already provides such a mechanism where there is a mistake as to ownership of the land between the owner and the adverse possessor. No action for recovery of land or adverse possession should be brought without relying on section 60 in the alternative. Expanding section 60 to cover the situation of the adverse possessor who knows title to the land is with someone else would not produce exceptional detriment to third parties but would provide some protection for the adverse possessor. Correcting this defect in the legislation, as has been done in the past, would increase the beneficial effects of adverse possession. Abolishing adverse possession is a step backward and would only cause further problems. 


\section{TABLE OF CONCORDANCE OF ALBERTA STATUTES}

\begin{tabular}{|c|c|c|c|c|}
\hline Legislation & Limitation of Actions & \multicolumn{3}{|c|}{ Land Titles } \\
\hline R.S.A. 1980 & c. L-15, ss. $18 \& 44$ & c. L-5, ss. $42-45$ & c. L-5, s. 74 & $\begin{array}{c}\text { Law of } \\
\text { Property } \\
\text { c. L-8, s. } 60\end{array}$ \\
\hline 1874 & [UK] c. 57, s. I & & & \\
\hline 1886 & & S.C. c. 26 , ss. $50-51$ & & \\
\hline 1893 & O.N.W.T., no. 28 , s. 1 & & & \\
\hline 1894 & & S.C. c. 28. ss. $45-46$ & & \\
\hline 1898 & C.o. c. 31 , s. 2 & & & \\
\hline 1906 & & S.A. c. 24 , ss. $32-37$ & & \\
\hline 1921 & & & s. 50 (a) & \\
\hline R.S.A. 1922 & c. 90, s. 3 & c. 133, ss. $41-45$ & c. 133, s. 64 & \\
\hline 1935 & S.A. c. 8 , ss. $17 \& 45$ & & & \\
\hline R.S.A. 1942 & c. 133, ss. $18 \& 46$ & c. 205, ss. $41-45$ & c. 205, s. 70 & \\
\hline 1950 & & & & s. $173(\mathrm{a})$ \\
\hline R.S.A. 1955 & c. 177, ss. $18 \& 44$ & c. 170, ss. $42-46$ & c. 170, s. 73 & c. 170, s. 183 \\
\hline R.S.A. 1970 & c. 290, ss. $18 \& 44$ & c. 198. ss. $41-45$ & c. 198, s. 73 & c. 198, s. 183 \\
\hline R.S.A. 1980 & c. L-15, ss. $18 \& 44$ & c. L-5, ss. $42-45$ & c. L-5, s. 74 & c. L-8, s. 60 \\
\hline
\end{tabular}

